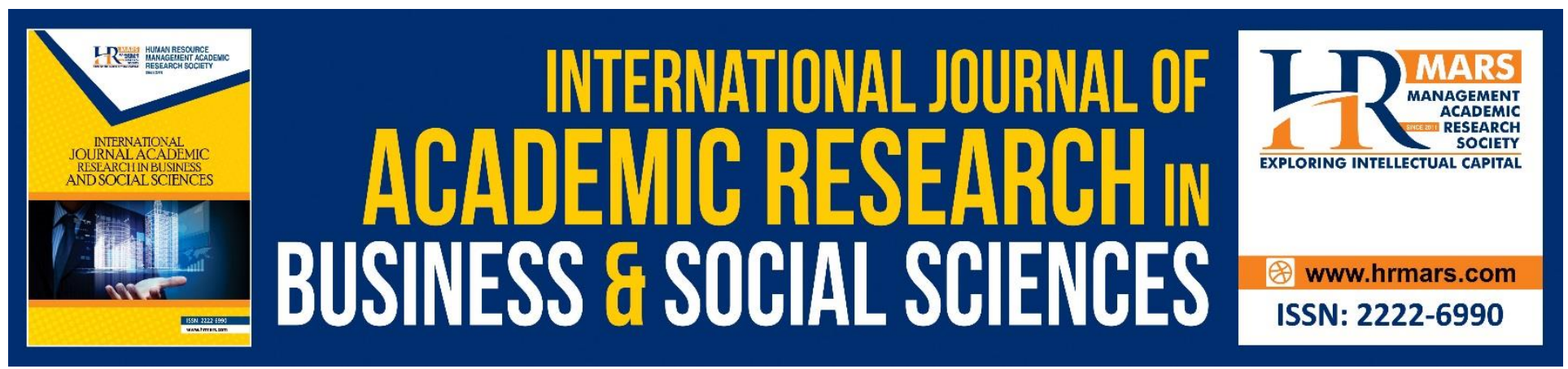

\title{
Modelling Social System for School Effectiveness
}

\author{
Abbas Sani Dahiru, Ramli Basri, Abubakar Abba Aji, Soaib Asimiran
}

To Link this Article: http://dx.doi.org/10.6007/IJARBSS/v8-i12/5004

DOI: $10.6007 /$ IJARBSS/v8-i12/5004

Received: 09 Oct 2018, Revised: 17 Nov 2018, Accepted: 13 Dec 2018

Published Online: 18 Dec 2018

In-Text Citation: (Dahiru, Basri, Aji, \& Asimiran, 2018)

To Cite this Article: Dahiru, A. S., Basri, R., Aji, A. A., \& Asimiran, S. (2018). Modelling Social System for School Effectiveness. International Journal of Academic Research in Business and Social Sciences, 8(12), 178-186.

Copyright: (C) 2018 The Author(s)

Published by Human Resource Management Academic Research Society (www.hrmars.com)

This article is published under the Creative Commons Attribution (CC BY 4.0) license. Anyone may reproduce, distribute, translate and create derivative works of this article (for both commercial and non-commercial purposes), subject to full attribution to the original publication and authors. The full terms of this license may be seen at: http://creativecommons.org/licences/by/4.0/legalcode

Vol. 8, No. 12, 2018, Pg. 178 - 186

http://hrmars.com/index.php/pages/detail/IJARBSS

JOURNAL HOMEPAGE

Full Terms \& Conditions of access and use can be found at http://hrmars.com/index.php/pages/detail/publication-ethics 


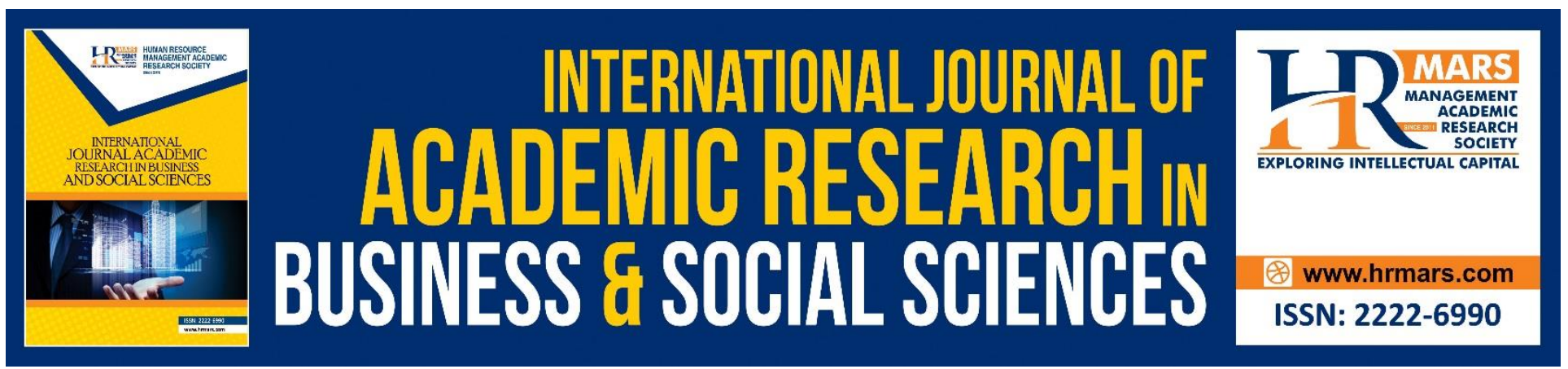

\title{
Modelling Social System for School Effectiveness
}

\author{
Abbas Sani Dahiru, Ramli Basri, Abubakar Abba Aji, Soaib Asimiran \\ Faculty of Educational Studies, Universiti Putra Malaysia, 43400 UPM Serdang, Selangor Darul \\ Ehsan, Malaysia
}

\begin{abstract}
School effectiveness is the level at which school is able to accomplish its pre-determined objectives with a view to solving the obstacles that might hinder the smooth running of schools. Although, substantial progress was theoretically achieved in defining effective schools, still there exists a dearth in models which researchers could rationalise and develop a theory that could best describe the phenomena. This paper explained the concepts of school effectiveness and social system as well as the role of social system theory in enhancing an effective school system. And finally the implications of the paper to the body of knowledge, policy makers and school principals were discussed in the paper.
\end{abstract}

Keywords: School Effectiveness, Social System Theory

\section{Introduction}

School effectiveness is considerably wider concept and as such, there are serious debates regarding its definition. The Coleman (1966) established that family background and socio-economics, instead of method of instruction and the school itself, were the main indicators of students achievement. However, since 1980s, researchers are of the opinion that schools were successful in educating all students irrespective of their socioeconomic status or family background. Though the main attention of early researches on effective schools was on student achievements, other researches assumed that other elements are greatly significant in ensuring the effectiveness of schools. Some researchers have concentrated on some school activities that include qualification of teachers, human, financial and material resources, teaching methodologies and class size, as a key issues influencing school effectiveness (Ghani et al., 2011; Lezotte \& Snyder, 2011). School effectiveness is concerned with the structures and culture of an institution and expressing the manners in which plans, policies and practices help in improving the overall objectives of the school and teacher effectiveness at the classroom level (Hargreaves, 2001). It encompasses the overall achievements of the students in all the three domains of learning.

Throughout the prescriptive phase (1985-1995) of the school effectiveness movement, researchers started to reflect on significant research contributions from other fields, including system 
organization (Lezotte \& Snyder, 2010). A social system refers to events and dealings of the members of a particular group or groups composed for a mutual determination. Usually, in a social system model there is an interaction and communication among every member in organizing and improving the social interaction (Thien \& Razak, 2014). According to Getzels and Guba (1957) social systems have two dimensions of interdependency and interaction. First dimension is related to the specific roles and anticipations that will aid in fulfilling the goals of the system. The second dimension is concerned with the individuals with specific qualities and need disposition occupying the system, whose interactions include observed conduct (Lunenburg, 2013).

Although, substantial progress was theoretically achieved in defining components of effective schools, still Mortimore et al., 1988; Scheerens, 1999; Levine \& Lezotte, (1990), there exists a dearth in models which researchers could rationalise and develop a theory (Scheerens \& Bosker, 1997; Scheerens, 2013). In view of the above, most extant research focusing on educational effectiveness are theoretical and mainly directed towards establishing statistical association between variables as against generation and theory testing, which could describe those relationship and its contribution to the establishment of strategies for improving effectiveness in educational setting (Creemers \& Kyriakides, 2008; 2010). Therefore, the aim of this paper is to discuss the critical role of the social system towards achieving an effective school system.

\section{Social System and School Effectiveness}

According to Hoy and Miskel (2013) all schools are open systems that comprise of inputs, transformation process, outputs, feedback and the environment (Aydin, Sarier, \& Uysal, 2013).The open-system portraits organization as not only affected by environments, but also dependent on them. Open-system's cyclic process, it starts with inputs, transformation and output. Organizations take inputs from the environment, transform them and produce outputs (Neal, 2013). 


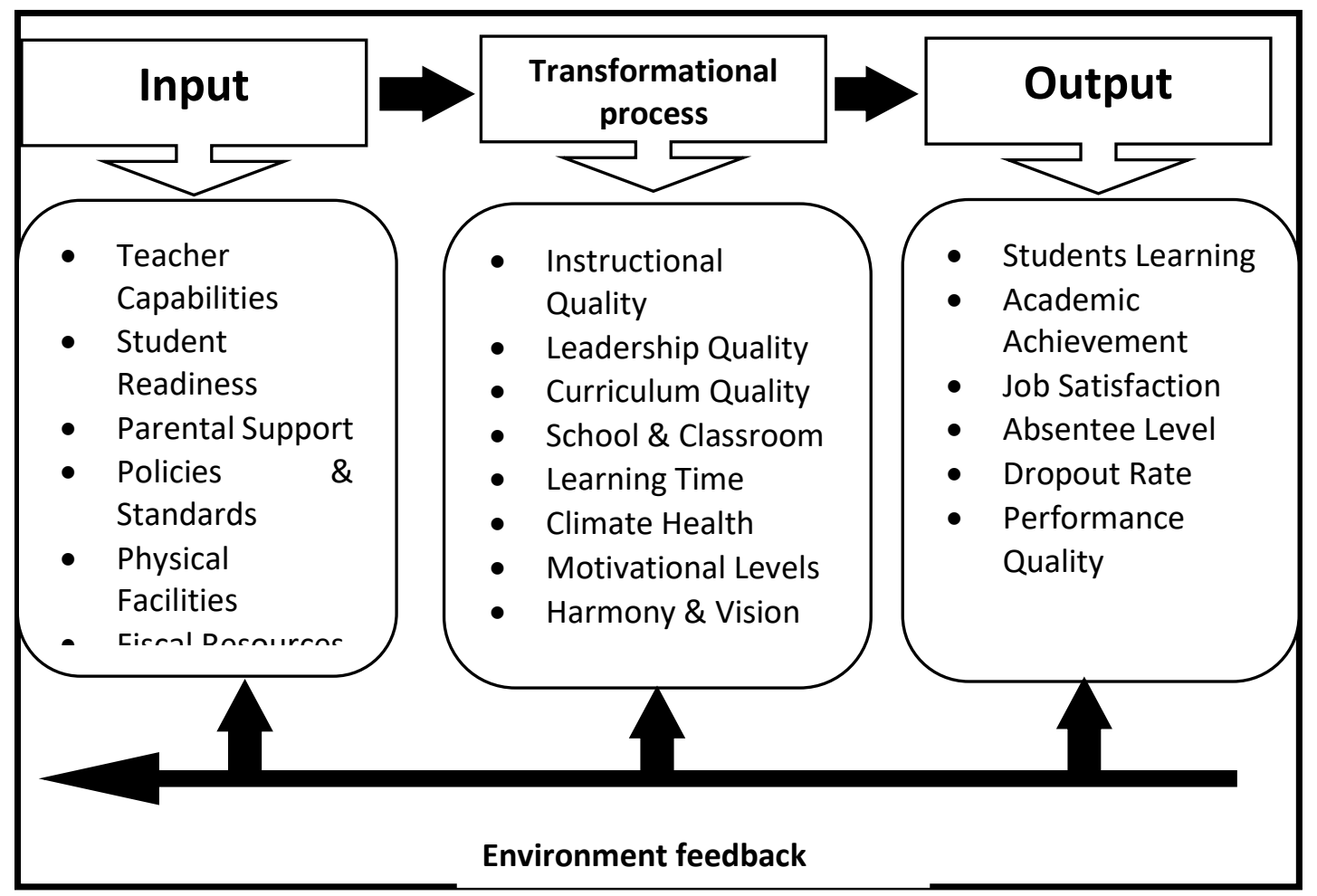

Figure 1 School effectiveness and open social system, Source: (Hoy and Miskel, 2013

According to Hoy and Miskel (2013) input criteria comprises of labours, students and money from the environment and other associated aspects such as human, material, financial or information resources. Transformational process denotes effective internal processes within the transformation process. In education it refers to the organization and content of the curriculum, health of the interpersonal climate, motivation levels of students and teachers, teacher and administrator leadership, quality and quantity of instruction, coordination and vision, learning time, school and classroom, shared efficacy and academic optimism (Hoy \& Miskel, 2013). Equally, according to Scheerens et al., (2007); Scheerens (2013) model of school effectiveness, the transformational process in open-system theory comprises of nine dimensions which are: effective leadership, effective teaching, considering on learning, generating a positive school culture, considering on high expectations for all, student tasks, monitoring progress across levels, increasing the skills of the staff as well as school home school relationship.

Furthermore, outputs of school as the third factor of open-system framework consists of the process of teaching and learning interactions. Indicators of effectiveness may arise from each stages of the cycle comprising input, transformation process and output (Aydin et al., 2013). From a social-system viewpoint, significant outputs for students comprise academic achievement, creativity, selfconfidence, goals, anticipations, graduation as well as the rates of dropout. On the part of the teachers, important outputs are job satisfaction, absence and turnover. Also, the outputs of opensystem for administrators include job satisfaction, balanced budgets and commitment to school. 
INTERNATIONAL JOURNAL OF ACADEMIC RESEARCH IN BUSINESS AND SOCIAL SCIENCES

Vol. 8, No. 12, Dec, 2018, E-ISSN: $2222-6990$ c 2018 HRMARS

Moreover, important outputs of social system for society comprise perception of school effectiveness. According to the outputs of the open-system based on goals and performance, a school is effective if the outcomes of its performance meet or surpass its goals (DiPaola \& Hoy, 2013). According to the framework of Hoy and Miskel (2013) which was developed based on Scott (2007) open social system theory, transformational process lay emphasis on five internal subsystems, they are: technical, structural, cultural, individual and political systems. Figure 2 shows the key components of a social system.

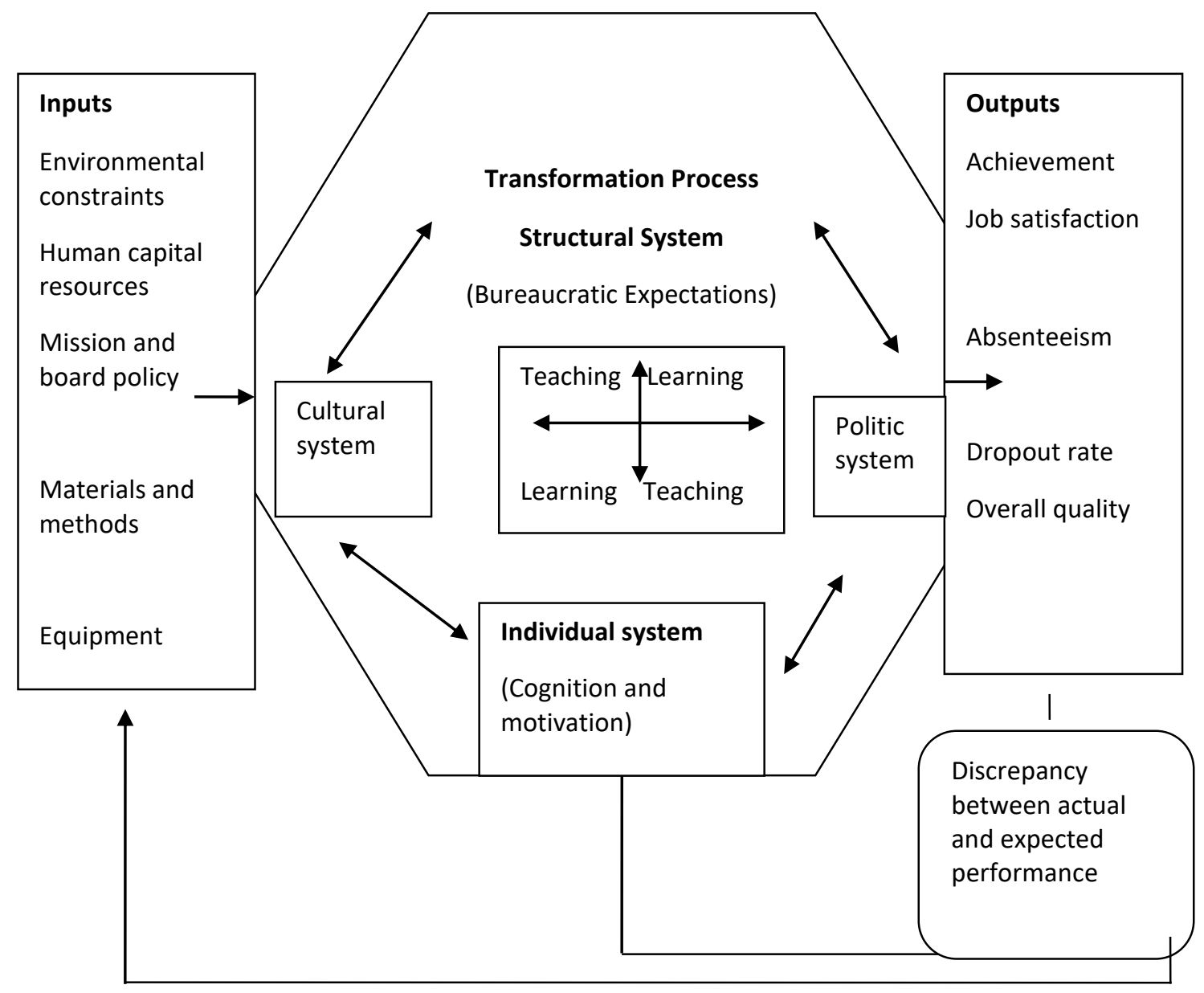

Figure Error! No text of specified style in document. Social system model for schools. Source: Hoy

St and Miskel (2013)

ch are $d \epsilon$ tudent

are essential and the positions are defined based on established anticipations. Members have their own desires, opinions, and intellectual visions towards their works. According to individual system irrespective of formal positions, it is presumed that a significant way to understand about 
administrators, teachers, students, and persons in the school as a social system is to examine their desires, views, objectives as well as inspirations (Hoy \& Miskel, 2013).

Culture system is referred to as a vibrant link between bureaucratic role demands and individual work which desires to take along people together in the place of work. Consequently, organizations need to design their own unique cultures. In school, shared values, norms, beliefs and way of thinking among teachers are shared orientations from the culture of the school and significantly have an influence on their conducts. Political system is a system of informal authority relationships that seem to resist other systems of control. Individuals that operate within the confines of the structure, culture and individual systems usually contribute to the needs of the organization (Hoy \& Miskel, 2013).

According to Scheerens (2013), there exist three different levels of structure in the organization. They are: institutional, technical and managerial. The institutional level relates the school with the outside environment. In schools, principals, administrators and teachers need to be reinforced for them to accomplish their tasks in a pleasant way that is devoid of unnecessary burden from outside of the school. The technical function is the process of teaching and learning as the back bone of all educational organizations. Technical core (teaching-learning process) is the system of organizational activity where the real out-put of the organization is produced. Like the organization, technical process in school is established by the teaching and learning in the classroom. The managerial system is in control of administering the internal affairs of the organizations (Hoy \& Miskel, 2013).

Generally, the technical process (teaching and learning process) as an important element of transformational process in open social system comprises all of the school activities that will lead to producing the real products of school and provides a vibrant picture of the school with the feedback mechanism. The internal components of social system are consistent with each other in a dynamic process to produce an effective school. Thus, it can be established that school effectiveness is positively related to the task of internal elements of social system (Tarter \& Hoy, 2004).

There exist in schools the basic features of the social system, which are, interaction of multiplicity of individuals, regular interaction within school communities and individuals with different roles and interact with each other with a view to attain the school goals (Katz \& Kahn, 1978). This subsequently characterizes school as a systematically arranged organization. As a result, it can be established that school is certainly a social system. However, school as a social system is not isolated from its surrounding environment; this is due to the fact that school interrelates consistently with the surrounding or environment as described by open system theory (Katz \& Kahn, 1978). There are three perceptions towards systems, which are rational-system, natural-systems and open-systems (Scott, 1998). The rational-system perspective considers organizations as formal instruments intended to reach predefined goals of organization with utmost efficiency. The natural-systems perspective is in disagreement with the rational-systems perspective. The natural-systems views organizations as organisms than machines. It is based on the human relations approach and similar to the rationalsystems model moved from a closed to open-systems perspective. By assuming the school as an open-system, both rational and natural systems are being considered. Clearly both formal and 
informal aspects, as well as structure and people, are essential to comprehend the organizations. Furthermore, the open-systems model has the potential to provide a synthesis by linking the rational and natural perspectives (DiPaola \& Hoy, 2013).

An effective school is a complex system in which staff commitment leads to managing and directing the interdependent elements in order to successfully accomplish the mission of learning (Lezotte \& Snyder 2010). According to the philosophy of effective school, the aim of school is that of teaching and learning, and the other elements must be seen as being service to it. According to Lezotte \& Snyder (2010), leading the school without assuming it as a system will be led to attaining the modest improvement. Components of a social system are essential for the survival of school as a system for they provide the leading indicators that have positive effect on student learning. Each of the components of a social system can be viewed as a necessary subsystem that meets the three standards of effective school, which are (1) have a clear goal and mission (2) being manageable (3) have a broad staff commitment to goal achievement (Deming, 1993; Lezotte \& Snyder, 2010).

Moreover, Scott (2007) indicated that all schools are open systems. Therefore, school and classroom can be viewed as a social system. Open systems consist of inputs (labour, students and money from the environment human, material, financial, or information resources), educational transformation process (quantity, quality, and consistency of the internal processes and structures that transform the inputs to output), outputs (enhances students, academic achievement, teachers' motivation and satisfaction), feedback and the environment (Parsons \& Halsey, 1959; Hoy and Miskel, 2013; Scott, 2007). According to Hoy \& Miskel (2013), outputs of schools are a function of the interaction of teaching and learning in the process of transformation, which, refer to the internal operations of effective school as an open system. According to the integrated model of organizational effectiveness by Hoy \& Miskel (2001), specific indicators of transformation process in open social system include instructional leadership, learning time, curriculum quality, school and classroom, climate health, harmony and vision, which can come from each phase of the cycles of the open social system model.

\section{Conclusion and Implications}

In order to improve the effectiveness of the schools, educators must focus on the leading indicators, which are those factors that influence the trailing indicators of productivity or performance (effectiveness). Thus, educators must institute changes in the social system as a critical factor in the enhancement of school productivity, since process of enhancing the feeling of self-efficacy among members in a school to increase their innovative behavior and effectiveness is supported by the social system.

Moreover, the school is considered as a social system its ability to add value to student learning is beyond what a single teacher can do working alone (Lezotte \& Snyder, 2011). The social system represents organizational schemes to align the student's learning experiences with many of the principles of human learning on a school wide basis. Therefore, according to Deming (1993) and Lezotte \& Snyder (2011), if the school is successful in adopting the components of a social system, school effectiveness and student performance will be improved. 
Lunenburg and Ornstein (2010) indicated that an effective school have some characteristics of a social system that includes; safe and orderly environment, clear school mission, instructional leadership, climate of high expectations, and time on task, frequent monitoring and positive home school relation. Maximizing effectiveness in schools, the internal component such as school structures, culture and climate, in addition to power and politics must form the motivational aspect of teaching and learning processes in schools, since the main components of open social system must work harmoniously to produce the desired goals (Tarter \& Hoy, 2004; Hoy \& Miskel, 2013). These internal elements increase the system's ability to secure needed resources from the environment and improved effectiveness. Hence, in this research, system theory perspective could be the best supports to determine the school effectiveness model (Scott, 2007; Lezotte \& Snyder, 2011; Scheerens, 1990; Hoy \& Miskel, 2001; 2013).

This paper denotes that social system theory is important and significant factor directly influencing school effectiveness. It is not out of place to state that, social system constituent promotes working environments with defined rewarding structure, supervisory practices, work policies and supportive management structures which are important features of effective school. This implies that, clearly defined work role where teachers are made to understand the goals and expectations of the schools, supported with adequate supervision, opportunities for participatory decision making, interaction flows that are governed by professionalism and competence, in addition to healthy teamwork enhances effectiveness of schools, thus, positive and greater work outcome. Teachers have greater motivation to self-develop in their skills and knowledge, and are more willing to harmonized or align their individual goals with that of the school and the community which are expected to greatly benefit the entire school. Hence administrators need to take in to cognizance the significance of social system in achieving school effectiveness.

\section{References}

Aydin, A., Sarier, Y., \& Uysal, S. (2013). The Effect of School Principals' Leadership Styles on Teachers' Organizational Commitment and Job Satisfaction. Educational sciences: Theory and practice, 13(2), 806-811.

Coleman, J. S., Campbell, E. Q., Hobson, C. J., McPartland, J., Mood, A. M., Weinfeld, F. D., \& York, R. (1966). Equality of educational opportunity. Washington, dc, 1066-5684.

Creemers, B. P., \& Kyriakides, L. (2008). The dynamics of educational effectiveness.

Creemers, B. P., Kyriakides, L., \& Sammons, P. (2010). Methodological advances in educational effectiveness research: Routledge.

DiPaola, M., \& Hoy, W. K. (2013). Improving instruction through supervision, evaluation, and professional development: Information Age Publishing Inc, North Carolina.

Getzels, J. W., \& Guba, E. G. (1957). Social behavior and the administrative process. The School Review, 65(4), 423-441.

Ghani, M. F. A. (2014). Development of Effective School Model for Malaysian School. Middle-East Journal of Scientific Research, 19(10), 1334-1346. 
Hargreaves, D. H. (2001). A capital theory of school effectiveness and improvement [1]. British educational research journal, 27(4), 487-503.

Hoy, W. K., Miskel, C. G. (2013). Educational Administration: M c Graw- Hill International.

Hoy, W. K., Tarter, C. J., \& Kottkamp, R. B. (1991). Open schools, healthy schools: Measuring organizational climate: Corwin Press.

Katz, D., \& Kahn, R. L. (1978). The social psychology of organizations (Vol. 2). New York: Wiley.

Lezotte, L. W., \& Snyder, K. M. (2010). What effective schools do: Re-envisioning the correlates: Solution Tree Press.

Mortimore, P., Sammons, P., Stoll, L., Lewis, D., \& Ecob, R. (1988). School matters: The junior years: Open Books.

Neal, L. A. (2013). An Analysis of Self-Assessed Leadership Styles and Interpersonal Communication Competencies of Kansas Public School Superintendents. Baker University.

Scheerens, J. (1999). School effectiveness in developed and developing countries: A review of the research evidence. World Bank, Human Development Network, Education Group, Washington, DC Processed.

Scheerens, J. (2013). The use of theory in school effectiveness research revisited. School effectiveness and school improvement, 24(1), 1-38.

Tarter, C. J., \& Hoy, W. K. (2004). A systems approach to quality in elementary schools: A theoretical and empirical analysis. Journal of Educational Administration, 42(5), 539-554.

Thien, L. M., \& Razak, N. A. (2014). Teacher commitment: a comparative study of Malaysian ethnic groups in three types of primary schools. Social Psychology of Education, 17(2), 307-326. 